\title{
Hubungan Faktor Risiko Lama Penggunaan Kontrasepsi Hormonal dengan Kejadian Kanker Payudara
}

\author{
Atania Rachma Anindita, ${ }^{1}$ Sri Mulya ${ }^{2}$ \\ ${ }^{1}$ Mahasiswa Program studi D III Kebidanan, Fakultas Kedokteran, Universitas Sebelas Maret \\ ${ }^{2}$ Dosen Program studi D III Kebidanan, Fakultas Kedokteran, Universitas Sebelas Maret
}

\begin{abstract}
Abstrak
Kanker payudara merupakan penyakit yang ditandai dengan terjadinya pertumbuhan berlebihan atau perkembangan tidak terkontrol dari sel atau jaringan payudara. Kontrasepsi hormonal merupakan salah satu faktor risiko kanker payudara. Data dari Dinas Kesehatan Kota Surakarta pada tahun 2014 terdapat $66,91 \%$ peserta keluarga berencana menggunakan kontrasepsi hormonal. Ini menunjukkan kontrasepsi hormonal lebih diminati dari jenis non hormonal. Penelitian ini menggunakan pendekatan case control terdiri dari variabel bebas lama penggunaan kontrasepsi hormonal dan variabel terikat kejadian kanker payudara. Data yang diperoleh dalam penelitian ini diolah menggunakan uji chi kuadrat. Pengambilan sampel dalam penelitian ini menggunakan teknik accidental sampling, dengan 30 responden kanker payudara dengan riwayat menggunakan kontrasepsi hormonal dan 30 responden akseptor kontrasepsi hormonal. Hasil dari total responden yang mengalami kanker payudara (sebanyak 30 responden), 61,5\% memiliki riwayat menggunakan kontrasepsi hormonal $\geq 5$ tahun. Berdasarkan hasil uji statistik diperoleh $\rho>0,05$ yaitu 2,443. Simpulan tidak ada hubungan antara lama penggunaan kontrasepsi hormonal dan kejadian kanker payudara di Surakarta tahun 2015.
\end{abstract}

Kata kunci: Kanker payudara, kontrasepsi hormonal, lama penggunaan. 


\title{
Correlation between Long Usage of KB Hormonal and Breast Cancer Incidences
}

\begin{abstract}
Breast cancer is a disease characterized by the occurrence of excessive growth or uncontrolled growth of cells or breast. Hormonal contraception is one of the factors triggering breast cancer. Data from the in district Health Service Surakarta in 2014 there were $66.91 \%$ of those using hormonal contraception. This showed the hormonal contraception is more desirable than non hormonal contraception.. This research used a case control approach consists of independent variable: hormonal contraception use duration and breast cancer incidence as dependent variable. Data obtained in this research is processed using chi-square test. The results of total respondents who have breast cancer (30 respondents), $61.5 \%$ had a history of using hormonal contraception is more than equal to 5 years. Based on chi square test result is the of $\rho>0.05$ is 2.443 . The conclusion, no correlation between duration of hormonal contraception and breast cancer incidences at Surakarta in 2015.
\end{abstract}

Keywords: Breast cancer, hormonal contraception, duration

\section{Pendahuluan}

Kontrasepsi hormonal merupakan alat atau obat kontrasepsi yang bertujuan untuk mencegah terjadinya kehamilan dengan bahan baku preparat estrogen dan progesteron. ${ }^{1}$ Penggunaan kontrasepsi hormonal sebagai salah satu alat kontrasepsi meningkat tajam. Menurut World Health Organization (WHO), dewasa ini hampir 380 juta pasangan menjalankan keluarga berencana dan 65-75 juta diantaranya menggunakan kontrasepsi hormonal, terutama di negara berkembang seperti kontrasepsi oral, suntik, dan implant. ${ }^{2}$ Hasil survei di Indonesia menunjukkan hasil 4.025.642 (11,41\%) akseptor Keluarga Berencana (KB) intra uterine device (IUD), $1.241 .758(3,52 \%)$ akseptor KB metode operasi wanita (MOW), 244.126 (0,69 \%) akseptor KB metode operasi pria (MOP), $1.136 .810(3,22 \%)$ akseptor KB kondom, $3.439 .453 \quad(9,75 \%)$ akseptor KB implant, $16.533 .106(46,87 \%)$ akseptor KB suntik, 8.655.210 (24,54\%) akseptor $\mathrm{KB}$ pil. ${ }^{3} \mathrm{Hal}$ ini menunjukkan bahwa kontrasepsi hormonal lebih banyak diminati akseptor daripada yang lain. Sejumlah penelitian sebelumnya menunjukkan adanya hubungan antara pemakaian kontrasepsi hormonal dan peningkatan risiko kanker payudara. $^{4}$

Kanker payudara merupakan penyakit yang ditandai dengan terjadinya pertumbuhan berlebihan atau perkembangan tidak terkontrol dari sel atau jaringan payudara. ${ }^{5,6}$ Salah satu alasan semakin berkembangnya kanker tersebut disebabkan oleh rendahnya cakupan deteksi dini atau screening. ${ }^{7,8}$

Berdasarkan latar belakang lebih banyak peminat kontrasepsi hormonal dari pada kontrasepsi lainnya, konsistennya jumlah akseptor di kisaran tersebut yang menandakan sebagian besar peserta tidak mengganti metode kontrasepsinya dan terus meningkatnya angka kejadian kanker tiap tahun, maka penulis tertarik mengkaji hubungan antara lama penggunaan kontrasepsi hormonal dan kejadian kanker payudara di Surakarta?"

\section{Metode}

Penelitian ini merupakan penelitian survei analitik dengan rancangan case control atau kasus kontrol dengan menggunakan pendekatan retrospektif sehingga dapat mempelajari hubungan antara lama penggunaan dan kontrasepsi hormonal dan kejadian kanker payudara.

Penelitian ini dilaksanakan di beberapa Pusat Kesehatan Masyarakat (Puskesmas) di Kota Surakarta. Populasi penelitian adalah wanita akseptor kontrasepsi hormonal yang menderita kanker payudara sebagai kelompok kasus berjumlah 30 responden dan wanita akseptor kontrasepsi hormonal yang tidak menderita kanker payudara sebagai kelompok kontrol berjumlah 30 responden. Teknik sampling yang digunakan dalam penelitian ini adalah accidental sampling. Penelitian ini dilakukan dengan mengambil kasus atau responden yang 
kebetulan ada di lokasi penelitian pada minggu ke-2 sampai ke-4 bulan Mei 2015.

Kriteria inklusi dalam penelitian ini yaitu wanita yang menggunakan atau pernah menggunakan kontrasepsi hormonal baik penderita kanker payudara maupun bukan di kota Surakarta, berusia antara 20-65 tahun. Kriteria eksklusinya yaitu penderita kanker payudara yang tidak mau menjadi responden dan wanita yang suspek kanker payudara.

Metode pengumpulan data pada penelitian ini adalah data primer yang diambil menggunakan metode wawancara langsung ke responden dengan kuesioner kemudian disusun dalam check list yang sudah dipersiapkan, dan data sekunder, yaitu data pasien kanker payudara dari catatan data medis pasien di kota Surakarta dari setiap Puskesmas serta hasil selanjutnya dimasukkan ke dalam lembar check list.

Pelaksanaan penelitian dilakukan dengan cara peneliti mengambil kasus kanker payudara di 3 Puskesmas yang berbeda yaitu Puskesmas Purwodiningratan, Puskesmas Nusukan, dan Puskesmas Manahan. Setelah mendapat data pasien kanker, peneliti melakukan kunjungan ke rumah pasien. Untuk kelompok kontrol, sampel diambil dari Puskesmas Ngoresan, Puskesmas Pajang, dan Puskesmas Gajahan. Analisis bivariat pada penelitian menggunakan uji chi kuadrat.
Hasil

Tabel 1 Distribusi Frekuensi Responden Berdasarkan Jenis kontrasepsi Hormonal yang Digunakan di Kota Surakarta

\begin{tabular}{|c|c|c|}
\hline Jenis & Frekuensi & $\%$ \\
\hline Pil KB & 9 & 30 \\
\hline Suntik & 16 & 53,33 \\
\hline Implant & 5 & 16,67 \\
\hline
\end{tabular}

Pemakaian kontrasepsi hormonal paling banyak yaitu suntik sebanyak 16 responden $(53,33 \%)$. Berdasarkan hasil penelitian kontrasepsi hormonal yang banyak digunakan berturut-turut adalah $\mathrm{KB}$ suntik $53,33 \%$, KB pil $30 \%$ dan yang terakhir adalah implant

Tabel 2 Distribusi Frekuensi Responden Berdasarkan Lama Penggunaan kontrasepsi Hormonal di Kota Surakarta

\begin{tabular}{lcc}
\hline \multicolumn{1}{c}{ Lama Penggunaan } & Frekuensi & $\boldsymbol{\%}$ \\
\hline$<5$ Tahun & 34 & 56,67 \\
$\geq 5$ Tahun & 26 & 43,33 \\
\hline Total & 60 & 100 \\
\hline
\end{tabular}

Tabel 3 Distribusi Frekuensi Responden Berdasarkan Kejadian Kanker Payudara

\begin{tabular}{lcc}
\hline $\begin{array}{c}\text { Kejadian Kanker } \\
\text { Payudara }\end{array}$ & Frekuensi & \% \\
\hline Positif & 30 & 50 \\
Negatif & 30 & 50 \\
\hline Total & 60 & 100 \\
\hline
\end{tabular}

Tabel 4 Hubungan antara Lama Penggunaan kontrasepsi Hormonal dan Kejadian Kanker Payudara di Kota Surakarta

\begin{tabular}{lcccc}
\hline Kanker Payudara & \multicolumn{2}{c}{ Positif } & \multicolumn{2}{c}{ Negatif } \\
\cline { 2 - 5 } Lama Penggunaan KB Hormonal & Frekuensi & \% & Frekuensi & \% \\
\hline$>5$ Tahun & 16 & 61,5 & 10 & 38,5 \\
< 5 Tahun & 14 & 41,2 & 20 & 58,8 \\
\hline Total & 30 & 50 & 30 & 50 \\
\hline
\end{tabular}

Pada penelitian yang dilakukan di beberapa Puskesmas di kota Surakarta terdapat 26 responden $(43,33 \%)$ yang telah menggunakan kontrasepsi hormonal $\geq 5$ tahun dan 34 responden $(56,67 \%)$ menggunakan kontrasepsi hormonal $<5$ tahun. Berdasarkan data tersebut dapat disimpulkan bahwa wanita di beberapa Puskesmas di kota Surakarta yang menggunakan $\mathrm{KB}$ hormonal $\geq 5$ tahun lebih sedikit, namun perbedaannya kecil dengan wanita yang memakai kontrasepsi homonal $<5$ tahun yaitu $16,67 \%$. Menurut hasil survei, hal ini dikarenakan kontrasepsi suntik dianggap mampu menghindari lupa dalam penggunaan kontrasepsi seperti pil dan lebih memudahkan karena akan diberikan kartu jadwal suntik 
selanjutnya, baik itu suntik 3 bulan maupun 1 bulan. Kontrasepsi suntik juga lebih dipilih karena risiko infeksi dan bekas sayatan seperti pada implant tidak perlu dihadapi klien.

Berdasarkan hasil penelitian ini, pengetahuan masyarakat mengenai kanker payudara seperti deteksi dini tanda kanker payudara dengan menggunakan metode pemeriksaan payudara sendiri (Sadari) sangat kurang. Beberapa Puskesmas kurang dalam memberikan penyuluhan mengenai sadari ini.

Berdasarkan uji statistik menggunakan komputerisasi dengan analisis chi kuadrat diperoleh hasil $\mathrm{p}>0,05$ yaitu 2,443 sehingga menunjukkan bahwa tidak ada hubungan yang bermakna secara statistik. Dari hasil perhitungan tersebut disimpulkan bahwa tidak ada hubungan antara lama penggunaan kontrasepsi hormonal dan kejadian kanker payudara di kota Surakarta.

Hal ini dapat disebabkan karena peneliti tidak mengontrol variabel perancu yaitu faktor risiko dari kanker payudara. Tidak seperti kanker leher rahim yang dapat diketahui etiologinya dan perjalanan penyakitnya secara jelas, penyakit kanker payudara belum dapat dijelaskan. Akan tetapi, banyak penelitian yang menunjukkan adanya beberapa faktor yang berhubungan dengan peningkatan risiko atau kemungkinan untuk terjadinya kanker payudara. ${ }^{9}$ Faktor itu disebut faktor risiko, bukan berarti perempuan tersebut pasti akan menderita kanker payudara. Banyak perempuan yang mempunyai satu atau beberapa faktor risiko tetapi tidak pernah menderita kanker payudara sampai akhir hidupnya, ${ }^{6}$ berikut adalah faktor risiko kanker payudara: faktor reproduksi (usia menarche dan siklus menstruasi, usia kehamilan pertama, paritas, menyusui), faktor endokrin (faktor endogen dan eksogen), densitas payudara, asupan alkohol, obesitas, genetik, kelainan payudara yang lainnya atau endometrium, usia, biopsi payudara, ras, pengaruh geografik dan populasi, pajanan radiasi, olahraga, toksin lingkungan, dan tembakan. ${ }^{10-12}$

Berdasarkan hasil survei penelitian yang telah dilakukan, faktor risiko yang memengaruhi kejadian kanker payudara pada penelitian ini, yaitu usia menarche dan siklus menstruasi, paritas, hormon eksogen, genetik, kelainan payudara yang lainnya atau endometrium, biopsi payudara, ras, toksin lingkungan. Hal ini diperkuat dengan penelitan di Rumah Sakit Umum Daerah Dr. Moewardi Surakarta yang mengatakan Kontrasepsi hormonal menaikkan risiko kanker payudara, tetapi bukan faktor peningkat yang signifikan. ${ }^{13}$ Perempuan pengguna kontrasepsi oral saat ini memiliki risiko satu seperempat kali lebih besar daripada perempuan yang telah berhenti menggunakannya sejak 10 tahun yang lalu, namun peningkatan risiko secara statistik tidak signifikan. ${ }^{4,14}$ Penelitian menyatakan, alat kontrasepsi hormonal jenis pil, lama penggunaan metode kontrasepsi, dan riwayat keluarga (variabel luar) berpengaruh baik secara statistik maupun secara klinis terhadap kejadian kanker payudara. ${ }^{6}$

Menurut penelitian Harianto dkk mengatakan meskipun pengguna pil kontrasepsi memiliki risiko 1,864 kali lebih besar dibanding bukan pengguna pil kontrasepsi kombinasi terhadap kejadian kanker payudara namun risiko tersebut tidak signifikan sebagai faktor peningkat risiko terjadinya kanker payudara, sehingga pil kontrasepsi kombinasi hanya sebagai faktor peningkat risiko yang ringan terhadap kejadian kanker payudara di Rumah Sakit Dr. Cipto Mangunkusumo. ${ }^{15}$

Sejumlah penelitian sebelumnya menunjukkan adanya hubungan antara pemakaian kontrasepsi hormonal dan peningkatan risiko kanker payudara. ${ }^{16}$ Namun beberapa penelitian lainnya tidak menunjukkan hubungan tersebut. Studi yang dilakukan di Indonesia memberikan kesimpulan yang lemah tentang pengaruh kontrasepsi oral terhadap risiko kanker payudara karena tidak mengendalikan faktor perancu di dalam desain penelitiannya maupun dalam menganalisis data. $^{4}$

\section{Simpulan}

Berdasarkan hasil analisis dan pembahasan yang telah diuraikan sebelumnya, maka dapat disimpulkan bahwa tidak ada hubungan antara lama penggunaan KB Hormonal dan kejadian kanker payudara di Kota Surakarta.

\section{Daftar Pustaka}

1. Baziad A. Kontrasepsi Hormonal. Jakarta: PT Bina Pustaka Sarwono Prawirohardjo, 2008.

2. BKKBN. Informasi Pelayanan Kontrasepsi. Jakarta: BKKBN. 2013. 
3. Maharani S. Kanker Mengenal 13 Jenis Kanker dan Pengobatannya. Yogyakarta: Katahati. 2012. Hlm 69_ 70.

4. Departemen Kesehatan RI. Laporan Pelaksanaan SUKERDA. Jakarta: DEPKES RI. 2008.

5. Apreliasari H. Risiko Riwayat Pemakaian Kontrasepsi Hormonal Terhadap Kejadian Kanker Payudara di RSUD Dr. Moewardi Surakarta [skripsi]. Surakarta : UNS; 2009.

6. Anggorowati L. Faktor Risiko Kanker Payudara Wanita. Jurnal Kesehatan Masyarakat. 2013;8(2):1-6.

7. Oktavianisya N. Pengaruh Penggunaan Alat Kontrasepsi Hormonal terhadap Kejadian Kanker Payudara di Rsd Dr. Soebandi Jember [skripsi]. Jember: Universitas Jember; 2011.

8. Trisnadewi N W. Faktor risiko kanker payudara pada wanita di RSUP Sanglah Denpasar. Public Health and Preventive Medicine Archive. 2012;1(2):8-16.

9. Priyatin C, Ulfiana E, dan Sumarni S. Faktor Risiko yang Berpengaruh terhadap Kejadian Kanker Payudara di RSUP dr. Kariadi Semarang. Jurnal Kebidanan. 2013;2(5):55-64.

10. Fitoni H. Faktor Risiko Kanker Payudara di RSUD dr. Soedarso Pontianak. Jurnal Mahasiswa PSPD FK Universitas Tanjungpura. 2014;1(1): 21-35.
11. Lumintang L M, Susanto A, Gadri R dan Djatmiko A. Profil Pasien Kanker Payudara di Rumah Sakit Onkologi Surabaya 2014. Indonesian Journal of Cancer. 2014;1(4):33-41.

12. Oktavianisya N. Risiko Riwayat Keluarga dan Penggunaan Alat Kontrasepsi Hormonal terhadap Kanker Payudara di RSD dr. Soebandi Jember. Strada Jurnal. 2013;2(1):40-51.

13. Oktaviana DN, Damayanthi E, dan Kardinah. Faktor Risiko Kanker Payudara pada Pasien Wanita I Rumah Sakit Kanker "Dharmais", Jakarta. Indonesian Journal of Cancer. 2012;1(1):1-8.

14. Sumari S, Ulfiana E dan Priyatin C. Faktor Risiko yang Berpengaruh Terhadap Kejadian Kanker Payudara di RSUP Dr. Kariadi Semarang. Jurnal Kebidanan. 2013;2(5): 68-75.

15. Harianto, Rina M, dan Hery S. Risiko penggunaan pil kontrasepsi kombinasi terhadap kejadian kanker payudara pada reseptor KB di perjan RS Dr. Cipto Mangunkusumo. Majalah Ilmu Kefarmasian. 2005; 2(1):84-99.

16. Nani D. Hubungan Umur Awal Menopause dan Status Penggunaan Kontrasepsi Hormonal dengan Kejadian Kanker Payudara. Jurnal Kesehatan Masyarakat. 2009;4(3):12-9. 